\title{
Teachers' Perceptions of Assessment and Feedback Practices in Finland's Foreign Language Classes During the Covid-19 Pandemic
}

Toni MÄKIPÄ̈̈ ${ }^{* 1}$, KAISA HaHL ${ }^{2}$ AND Milla LuOdonPä̈̈-MANNI ${ }^{2}$

$\approx$ In this paper, we examine how the Covid-19 pandemic affected the quality of teachers' assessment and feedback in Finland's foreign language classes during the remote teaching period in spring 2020. Multifaceted assessment and feedback practices are underscored in Finland's core curricula, forming a focal aspect of learning. Therefore, we studied teachers' perceptions of their assessment and feedback practices at different school levels during the remote teaching period and how they considered the remote teaching period in students' final assessment at the end of basic education. Data were collected through an online questionnaire and analysed using both quantitative and qualitative methods. Most of the 176 respondents felt that assessment and feedback practices were implemented successfully, and the final assessment was realistic and reliable. However, teachers' perceptions were mixed on several issues, and differences were found in the amount and form of feedback between respondents and school levels or what competence demonstration or assignments to count towards the final assessment. In addition, the remote teaching period usually had less influence on students' final grades than the last few months of basic education. The results suggest that more attention should be paid to enhancing feedback practices and connecting with students during remote teaching periods.

Keywords: assessment, feedback, foreign language teaching and learning, remote teaching

$1 \quad{ }^{*}$ Corresponding Author. Faculty of Educational Sciences, University of Helsinki, Finland; toni.makipaa@helsinki.fi.

2 Faculty of Educational Sciences, University of Helsinki, Finland. 


\section{Učiteljevo zaznavanje ocenjevalnih praks in povratnih informacij pri pouku tujega jezika na Finskem med pandemijo covida-19}

Toni MäKIpäÄ, Kaisa Hahl In Milla LuOdonpäÄ-ManNi

$\approx$ V prispevku preučujemo, kako je pandemija covida-19 vplivala na kakovost učiteljevega ocenjevanja in podajanja povratnih informacij pri pouku tujega jezika na Finskem med poukom na daljavo spomladi 2020. $\mathrm{V}$ finskih učnih načrtih so poudarjene večplastne prakse ocenjevanja in podajanja povratnih informacij; te predstavljajo osrednji vidik učenja. Zato smo preučevali, kako učitelji zaznavajo svoje prakse ocenjevanja in posredovanje povratnih informacij na različnih ravneh šole v obdobju poučevanja na daljavo ter kako upoštevajo obdobje poučevanja na daljavo pri sklepnem ocenjevanju učencev ob koncu osnovnega izobraževanja. Podatki so bili zbrani s spletnim vprašalnikom ter analizirani s kvantitativnimi in kvalitativnimi metodami. Večina izmed 176 anketirancev je menila, da se prakse ocenjevanja in posredovanja povratnih informacij izvajajo uspešno ter da je končna ocena realna in zanesljiva. A zaznavanja učiteljev glede več vprašanj so bila različna, ugotovljene pa so bile tudi razlike $\mathrm{v}$ količini in obliki povratnih informacij med anketiranci in ravnmi šol ter $\mathrm{v}$ tem, katere izražene kompetence ali naloge se upoštevajo pri končni oceni. Poleg tega je imelo obdobje pouka na daljavo običajno manjši vpliv na končno oceno učencev kot zadnjih nekaj mesecev osnovnega izobraževanja. Izsledki kažejo, da bi bilo treba več pozornosti nameniti izboljšanju prakse posredovanja povratnih informacij in povezovanju $\mathrm{z}$ učenci $\mathrm{v}$ obdobjih poučevanja na daljavo.

Ključne besede: ocenjevanje, povratna informacija, poučevanje in učenje tujih jezikov, poučevanje na daljavo 


\section{Introduction}

This study aimed to investigate how the Covid-19 pandemic affected Finnish language teachers' assessment and feedback practices during the remote teaching period between March and May 2020. More specifically, we examined whether teachers were satisfied with their assessment and the quality, amount, and forms of feedback they gave to their students. We also explored the key content areas on which they focused in their assessment and feedback practices.

Throughout this paper, we use the term 'student' to refer to pupils and students of all ages. Finnish students usually start first grade the year they turn seven. They study for the first six years at the primary school level, after which they continue at the lower secondary school level for three years. In other words, basic education lasts nine years, after which students usually continue their education in either a vocational school or a general upper secondary school for three more years. In 2019, the number of students in basic education was 564,100, 105,200 in general upper secondary education, and 320,100 in vocational education (Statistics Finland, 2021).

In March 2020, because of the massive outburst of the coronavirus in Finland and elsewhere in the world, all the schools in Finland were closed for two months, and teaching was undertaken remotely. Some schools remained open with specific arrangements for students with special needs or for students in Grades 1 to 3 who could not participate in remote teaching. In May, it was decided that students in basic education (Grades 1-9; comprehensive school) would return to contact teaching, and the continuation of remote teaching was recommended for other levels. Teachers had only a couple of days to prepare for this unprecedented change in March 2020. Several inherent issues related to teaching had to be reorganised, such as the teaching itself, assessment, feedback, homework, assignments, projects, support, and communication and contact with students. Fortunately, online platforms are widely used in Finnish schools, which alleviated the transition slightly, especially for older students. However, not all students had laptop computers or other necessary devices at home (Ahtiainen et al., 2020). Furthermore, half of Finland's teachers in basic education have only basic IT skills, and 10\% have inadequate IT skills (Tanhua-Piiroinen et al., 2020).

Teachers are expected to give multifaceted feedback to their students, and their assessment practices should be diverse (FNBE, 2016a, 2016b; Vocational Education and Training Act, 531/2017). Feedback is indispensable in language teaching (Mackey et al., 2016) as students can move forward in the 
learning cycle with the help of their teachers' feedback (Hattie \& Timperley, 2007), and feedback fosters students' motivation (Dörnyei, 2020). Therefore, studying how the remote teaching period affected language teachers' assessment and feedback practices, as well as how teachers considered the final assessment of $9^{\text {th }}$ graders, is instrumental. In this study, we examined teachers' perceptions of the assessment and feedback practices that they used. Peer assessment and self-assessment were excluded from our study. We will first discuss assessment and feedback practices in schools and then continue with an examination of remote teaching and its implementation during the Covid-19 pandemic in Finland. The next sections describe the data and methods of this study and present the results. Finally, we end the article with a discussion about the results and implications for further studies and practices.

\section{Assessment and feedback in schools}

In language teaching, assessment is often either summative or formative: the former referring to assessment after the learning process and the latter referring to assessment during the learning process. However, teachers can also use diagnostic assessment at the beginning of the teaching unit to assess the general level of the students (Linnakylä \& Välijärvi, 2005). Other terms are also used for summative and formative assessment, such as achievement assessment and progress assessment, as well as assessment of learning and assessment for learning. Even though assessment does not only refer to tests (Purpura, 2016), it seems that Finnish teachers are prone to using more summative than formative assessment (Mäkipää \& Ouakrim-Soivio, 2019), and exams, which are typical for summative assessment, are much used in foreign language teaching (Pollari, 2020). However, as noted by Butler and McMunn (2014), all types of assessment are needed in teaching, but teachers should use an ample variety of assessment methods and determine the pertinent assessment methods for each situation (Anderson, 2003). Nevertheless, foreign language teachers do not always know how to implement formative assessment into teaching (Tsagari, 2016).

Feedback is an inherent part of formative assessment. According to a definition provided by Hattie and Timperley (2007), feedback refers to the information given by an agent (such as a teacher) concerning performance or understanding. Feedback is an essential feature of the learning process (Wisniewski et al., 2020). Feedback needs to be clear, accurate, precise, selective, and timely (Butler \& McMunn, 2014). Moreover, effective feedback is based on learning goals (Ruiz-Primo \& Brookhart, 2018), explains where the student has succeeded and failed (Hattie \& Zierer, 2019), and enhances students' self-regulatory capacities (Hattie \& Timperley, 2007). In remote teaching, it is also of the utmost 
importance to be skilled in providing online feedback as it differs significantly from face-to-face feedback (Leibold \& Schwarz, 2015). Thus, feedback, particularly supportive feedback, is a key success factor in online teaching (Simons et al., 2020).

\section{Implementation of remote teaching}

Several terms are used for teaching that takes place remotely without the students and teachers physically in the same location. These terms include (but are not restricted to) distance teaching, remote teaching, distance education, open learning, and online learning. Their definitions may be similar or have distinct variations. Remote or distance-based teaching is not a new phenomenon, but with the internet and digitalisation, the conditions for it have gradually changed and improved. According to Simonson and Seepersaud (2019), the definition of distance education includes four components. The first is that distance education is institutionally based (as opposed to self-study), and the second is the separation of teachers and students. They must be separated in different physical locations but may also be separated in time and function asynchronously. The third component is interaction through different forms of telecommunication, such as the internet and a range of online platforms, but it could also be television, telephone, or even postal services. The final component is the interconnectedness of teachers, students, and learning resources (Simonson \& Seepersaud, 2019). Distance education has become common in many universities, and many Massive Open Online Courses (MOOCs) are offered - sometimes free of charge - to anyone interested.

Distance education has generally been geared mostly to adults and only recently to school students (Hilli, 2020). Remote teaching has become more common in school education for students in countries that are scarcely populated or in situations in which bullying, safety, or students dropping out is an issue (Toppin \& Toppin, 2016). Globally, remote teaching has offered rural schools better opportunities to employ qualified teachers to organise the teaching of less common subjects or smaller groups of students from several schools (Hilli, 2020; Toppin \& Toppin, 2016). In Sweden, for example, the government has been allowing the use of remote teaching by using digital technologies since 2015 (Stenman \& Pettersson, 2020). However, in Finland, in ordinary circumstances, legislation stipulates that teachers must be present to give students guidance in basic education. Therefore, remote teaching - without an adult overseeing the teaching situation - is not permitted.

Remote teaching, especially synchronous teaching, depends on digital technology, but it also relies on teachers' ability and skill to design and 
implement high-quality teaching in digital environments (Stenman \& Pettersson, 2020). A guiding principle behind Finnish education is equality (Niemi et al., 2016). Thus, all children should be provided with equal opportunities and access to high-quality education irrespective of their background or where they live. In general, the responsibility for implementing education and educational quality in Finland is held by local authorities (Niemi et al., 2016). Thus, schools (and the teachers) choose the methods and materials for education, including the assessment methods. The Finnish National Agency for Education recommended that schools adopt flexible forms of operation as they prepared the move to special arrangements and remote teaching, to 'aim at deviating from normal operation as little as possible' (Finnish National Agency for Education, 2020). However, as there are several ways to organise teaching in different schools, at different levels, and with different teachers even in ordinary circumstances, the implementations for remote teaching were diverse.

The Trade Union of Education in Finland (OAJ) distributed a questionnaire to teachers at all school levels and received over 5,500 responses in spring 2020. According to the review, most teachers in basic and upper secondary education (about 70\%) believed that, in general, the arrangements during the exceptional remote teaching period functioned well (OAJ, 2020). However, not all teachers had computers or mobile phones provided by their employers, and thus they had to use their own. In addition, most upper secondary school students were already familiar with the programmes and platforms they used during the remote teaching period, but this was not the case with many comprehensive school students who had to learn to use these programmes and tools. More than half of the teachers also believed that the remote teaching period would significantly negatively affect individual students and students, although they felt most would fare adequately.

Nevertheless, $75 \%$ of the respondents also felt that the remote teaching period would have positive effects on at least individual students, for example, those individuals who have trouble concentrating in a large class. Teaching was not always live online teaching: about $60 \%$ of teachers in comprehensive school and $54 \%$ in upper secondary school had taught synchronously according to weekly schedules. Students were also given different task packages, either for specific lessons or daily or weekly work (OAJ, 2020).

Another large-scale questionnaire study was done in spring 2020 by researchers at two Finnish universities (Ahtiainen et al., 2020). This study received over 5,300 responses from comprehensive school teachers (and had separate questions for principals, students, and guardians). Although most teachers found their own devices $(84 \%)$ and internet connection $(74 \%)$ to be 
functioning well, students' devices $(51 \%)$ and internet connection (38\%) functioned well less often (Ahtiainen et al., 2020, p. 17). Furthermore, during the remote teaching period, only $45 \%$ of teachers felt that they could fully assess their students' performance in different subjects or confirm that they completed all assigned tasks (Ahtiainen et al., 2020, p. 19). In addition, almost all teachers considered that the remote teaching period had increased their workload (Ahtiainen et al., 2020; OAJ, 2020). A case study by Niemi and Kousa (2020) found similar results regarding teachers' increased workload. In that study, teachers were also worried about the reliability of student assessment and the lack of normal interaction with students (Niemi \& Kousa, 2020).

These prior studies provide important insight into aspects of teaching and learning during the remote teaching period in Finland. However, little is known of assessment and feedback practices that are incremental components of learning situations (e.g., FNBE, 2016a, 2016b; Mackey et al., 2016). The current study contributes new information from the perspective of foreign language teachers. This study aims to understand assessment and feedback practices in foreign language teaching during the remote teaching period 13 March to 13 May 2020. Four research questions in relation to the remote teaching period are examined: 1) How did language teachers perceive the assessment practices? 2) How did language teachers perceive the feedback practices? 3) How realistic and reliable was the final assessment of $9^{\text {th }}$ graders, as perceived by language teachers? 4) Which issues did teachers focus on in the final assessment of $9^{\text {th }}$ graders?

\section{Method}

The research approach taken in this study is a mixed methodology based on closed- and open-response items in an online questionnaire. The respondents were Finnish foreign language teachers at all school levels.

\section{Online questionnaire}

The research data were collected using an online questionnaire. The questionnaire was divided into six sections which explored various aspects of the remote teaching period. Each section consisted of several closed-response items (on a Likert scale 1-5) designed to explore each topic's different aspects. Some of the items were deliberately redundant in order to increase the validity and reliability of the results. Asking the same question several times from slightly varied viewpoints makes the measurement more solid: the results do not depend on one question only (see, e.g., Vanhatalo \& Vehkalahti, 2020). The 
closed-response items were accompanied by five open-response items. This study focused only on teachers' perceptions of assessment and feedback practices during the remote teaching period.

The questionnaire was pilot tested in June 2020. After the pilot study, we decided to delete some items that were not at the heart of our research to reduce the required response time to 15-20 minutes. The questionnaire was launched in September 2020, and it was open for three weeks. The invitation to participate was sent to language teachers in Facebook groups dedicated to language teachers and through mailing lists from local and national foreign language teacher member associations of The Federation of Foreign Language Teachers in Finland (SUKOL). About 4,0oo language teachers are members of SUKOL (SUKOL, 2020). Therefore, the questionnaire was widely available to practising foreign language teachers in Finland. Like most online questionnaires, our study is subject to a self-selection bias: 'only people who are interested in a topic and feel strongly about it, whether positively or negatively, will be willing to spend 20 minutes filling out an online questionnaire on it' (Dewaele, 2018, p. 273). However, the strongest feelings about the remote teaching period in spring 2020 may have cooled down by the launch of the questionnaire in September.

\section{Respondents}

By the end of the survey period, data had been collected from 207 teachers. However, 31 respondents had only answered the background section of the questionnaire and these answers were excluded. Consequently, 176 answers were analysed for this study. Regarding gender, 164 were female (93\%), nine were male $(5 \%)$, and three did not reveal their gender $(2 \%)$. Nearly every respondent was a qualified teacher with a master's degree, including the study of pedagogy, and a sufficient amount of completed studies in a foreign language $(N=170,97 \%)$. Regarding age, most teachers were aged 40-49 $(N=61), 30-39$ $(N=49)$, or $50-59(N=44)$.

Concerning teaching experience, the respondents were mostly well-experienced teachers: 62 teachers had been teaching for ten or fewer years (35\%), while 53 had 11-20 years of experience (30\%), and 61 had been teaching for more than 20 years $(35 \%)$. Only nine respondents had taught for fewer than two years. Nearly half $(N=87,49 \%)$ of the respondents live in the metropolitan area of Helsinki. The languages taught by the teachers are shown in Table 1. 
Table 1

All respondents' teaching subjects (languages)

\begin{tabular}{lcc}
\hline Language & Number & \% of all the teachers \\
\hline English & 112 & 64 \\
Swedish & 88 & 50 \\
German & 33 & 19 \\
French & 32 & 18 \\
Spanish & 16 & 9 \\
Russian & 6 & 3 \\
Italian & 4 & 2 \\
Finnish & 3 & 2 \\
Japanese & 2 & 1 \\
Latin & 1 & 1 \\
Finnish as a second language & 1 & 1 \\
Finnish sign language & 1 & 1 \\
\hline
\end{tabular}

As shown in Table 1, the most commonly taught languages were English and Swedish (both of which are usually mandatory for students). Regarding optional languages, especially German, French, and Spanish teachers were represented in our data. Information on the levels at which the teachers teach is displayed in Table 2.

\section{Table 2}

The level of school at which the respondents teach

\begin{tabular}{lcc}
\hline School levels & $\begin{array}{c}\text { At which levels the } \\
\text { teachers teach }\end{array}$ & $\begin{array}{c}\text { Based on which school } \\
\text { the teachers answered }\end{array}$ \\
\hline primary & 72 & 38 \\
lower secondary & 85 & 63 \\
upper secondary & 66 & 55 \\
vocational & 3 & 2 \\
adult education and training & 23 & 18 \\
\hline
\end{tabular}

Regarding schools, most of the respondents work at lower secondary $(N$ $=85)$ and primary $(N=72)$ levels of the comprehensive school as well as general upper secondary schools $(N=66)$. The answers for this study came particularly from the perspective of the lower secondary level and general upper secondary school, presumably because those are the levels at which most subject teachers 
work, and the questionnaire was geared more to them. Furthermore, summative assessment does not traditionally have as large a role in adult education and training as in basic and upper secondary education. As the table implies, many teachers work at more than one level.

All the responses were anonymous, but the respondents were invited to leave their contact information if they wished to participate in a follow-up interview (beyond the scope of the present study).

\section{Methods of analysis}

The data were analysed using both quantitative and qualitative methods. The quantitative data were analysed with descriptive statistics, one-way ANOVA, and one-way MANOVA in SPSS version 25. All the I do not know / It does not concern me answers were excluded in the quantitative analysis. Furthermore, the non-parametric Mann Whitney U and Kruskal-Wallis tests were also conducted to examine all the claims as the data were not evenly distributed. In cases in which there were differences between the tests, only the non-parametric results have been shown.

The qualitative data in the open-response items were analysed with thematic analysis (Braun \& Clarke, 2006), using the Atlas.ti programme. The analysis was carried out as an iterative process through which the data were read through multiple times while looking for repetitive content that was then labelled with themes raised from the data. The similar themes and content were finally grouped into larger categories in accordance with the related research questions.

\section{Results}

In this section, the results are presented in the order of the research questions. When the results of the descriptive statistics are displayed, the answers are divided into three groups: disagreement (Likert 1-2), neutral (Likert 3), and agreement (Likert 4-5).

\section{Assessment practices perceived by language teachers}

The first research question aimed to study how language teachers perceived the assessment practices during the remote teaching period. Table 3 displays the answers to the questionnaire statements targeted at this question. 


\section{Table 3}

Teachers' perceptions of the assessment practices during the remote teaching period

\begin{tabular}{lcccccc}
\hline Item & Disagreement & Neutral & Agreement & All & M & SD \\
\hline $\begin{array}{l}\text { Assessing students in remote } \\
\text { teaching was easy for me. }\end{array}$ & $26 \%$ & $30 \%$ & $44 \%$ & 157 & 3.22 & 1.09 \\
\hline $\begin{array}{l}\text { I was able to assess students } \\
\text { equally during remote teach- } \\
\text { ing. }\end{array}$ & $16 \%$ & $31 \%$ & $53 \%$ & 154 & 3.42 & 1.00 \\
\hline $\begin{array}{l}\text { I am satisfied with my assess- } \\
\text { ment practices during the } \\
\text { remote teaching period. }\end{array}$ & $9 \%$ & $21 \%$ & $70 \%$ & 157 & 3.78 & .92 \\
\hline $\begin{array}{l}\text { Assessment was more chal- } \\
\text { lenging for me than before. }\end{array}$ & $25 \%$ & $21 \%$ & $54 \%$ & 154 & 3.38 & 1.15 \\
\hline $\begin{array}{l}\text { In my opinion, the assessment } \\
\text { of students during remote } \\
\text { teaching does not realistically } \\
\text { reflect their learning. }\end{array}$ & $43 \%$ & $26 \%$ & $31 \%$ & 153 & 2.73 & 1.21 \\
\hline
\end{tabular}

Note. $M=$ mean, $S D=$ standard deviation, $A l l=$ the number of analysed answers

As Table 3 displays, the overall response to this question was positive: teachers felt that assessment was somewhat easy, that they were satisfied with the practices they used, and that they could assess their students. However, the answers were mixed, particularly in the first and the last items. While assessment during the remote teaching period was easy for many respondents, it was not so for all. Similarly, although most of the respondents felt that the assessment during remote teaching reflected student learning realistically, a considerable number of teachers disagreed. In the open-response items, some of the respondents commented on the challenges they had faced with the assessment. For example, some respondents' experience was that there was an opportunity for cheating when assignments were turned in remotely, and some students may have done so. See more in the section Consideration of students' course work and competence demonstrations in final assessment (below).

\section{Language teachers' feedback practices}

The second research question focused on how language teachers perceived and implemented the feedback practices during the remote teaching period. The results for this question are shown in Table 4. 


\section{Table 4}

Teachers' perceptions of their feedback practices during the remote teaching period

\begin{tabular}{lcccccc}
\hline Item & Disagreement & Neutral & Agreement & All & M & SD \\
\hline $\begin{array}{l}\text { During remote teaching, I gave } \\
\text { as much feedback as before. }\end{array}$ & $38 \%$ & $21 \%$ & $41 \%$ & 162 & 3.09 & 1.18 \\
\hline $\begin{array}{l}\text { I regularly gave feedback to my } \\
\text { students. }\end{array}$ & $8 \%$ & $16 \%$ & $76 \%$ & 160 & 4.06 & .98 \\
\hline $\begin{array}{l}\text { I regularly commented on my } \\
\text { students' progress. }\end{array}$ & $12 \%$ & $22 \%$ & $66 \%$ & 158 & 3.78 & 1.07 \\
\hline
\end{tabular}

As shown in Table 4, teachers felt they regularly gave feedback and commented on their students' progress. Interestingly, much variation was found in the first claim, indicating extremely varied practices between the teachers regarding the amount of feedback given. The remote teaching period has affected the amount of feedback given by the teachers, depending on whether it was oral or written feedback. When asked how their oral feedback practices had been affected, $26 \%$ of the respondents reported that oral feedback had decreased 'somewhat', and $32 \%$ reported that oral feedback had decreased 'considerably'. For written feedback, the influence of the remote teaching period was the opposite. Out of the respondents, $56 \%$ reported that written feedback increased 'considerably', and 26\% reported that it had increased 'somewhat'. Further statistical tests reveal significant differences in the feedback practices, especially between lower secondary school teachers and upper secondary school teachers. See more in the section Statistically significant differences in the items (below).

\section{Reliability of $9^{\text {th }}$ graders' final assessment}

The third research question aimed to discern how realistic and reliable language teachers considered the final assessment of $9^{\text {th }}$ graders finishing basic education. These questions were only targeted at teachers teaching the $9^{\text {th }}$ grade, which explains the lower number of answers than the previous items. Table 5 provides the results for this question. 


\section{Table 5}

Teachers' perceptions of the final assessment of 9 th graders

\begin{tabular}{lcccccc}
\hline Item & Disagreement & Neutral & Agreement & All & $M$ & $S D$ \\
\hline $\begin{array}{l}\text { In my opinion, the final assessment } \\
\text { in the 9 } 9^{\text {th }} \text { grade was fair. }\end{array}$ & $10 \%$ & $7 \%$ & $83 \%$ & 73 & 4.22 & 1.07 \\
\hline $\begin{array}{l}\text { In my opinion, the grades of the } \\
\text { final assessment for the 9 } 9^{\text {th }} \text { graders } \\
\text { in spring 2020 are comparable to } \\
\text { previous years. }\end{array}$ & $11 \%$ & $16 \%$ & $73 \%$ & 70 & 3.99 & 1.20 \\
\hline $\begin{array}{l}\text { The final assessment of } 9^{\text {th }} \text { graders } \\
\text { was not realistic in spring 2020. }\end{array}$ & $75 \%$ & $15 \%$ & $10 \%$ & 69 & 1.91 & 1.04 \\
\hline
\end{tabular}

As Table 5 indicates, the respondents were unanimous about the reliability of the final assessment, and they perceived that $9^{\text {th }}$ graders were assessed fairly. These results, therefore, differ from the previous quantitative results as these results display scarcely any variation between the respondents.

\section{Statistically significant differences in the items}

Using one-way ANOVA and one-way MANOVA, we examined whether statistically significant differences could be detected in these 11 items. We used the type of school, age group, teaching experience, and location as independent variables. Regarding the type of school, vocational school and adult education were excluded from the analysis due to there being few participants in these groups. Similarly, the age groups 20-29 and 60+ were excluded. Further analyses showed statistically significant differences in two claims regarding the type of school: I regularly gave feedback to my students, and I regularly commented on my students' progress. Table 6 provides the results obtained from the analyses.

\section{Table 6}

Items with statistically significant differences

\begin{tabular}{lccccccccc}
\hline Item & M & SD & M & SD & M & SD & F & p & $\eta^{2}$ \\
\hline $\begin{array}{l}\text { primary } \\
(N=35)\end{array}$ & & $\begin{array}{c}\text { lower } \\
\text { secondary } \\
(N=57)\end{array}$ & $\begin{array}{c}\text { upper } \\
\text { secondary } \\
(N=53)\end{array}$ & & & & & & \\
\hline $\begin{array}{l}\text { I regularly gave } \\
\text { feedback to my } \\
\text { students. }\end{array}$ & 4.06 & 1.11 & 4.35 & .72 & 3.81 & 1.08 & 4.350 & $.015^{*}$ & .06 \\
\hline $\begin{array}{l}\text { I regularly } \\
\text { commented on } \\
\text { my students' } \\
\text { progress. }\end{array}$ & 3.71 & 1.07 & 4.14 & .83 & 3.57 & 1.17 & 4.597 & $.012^{*}$ & .06 \\
\hline
\end{tabular}

Note. ${ }^{*}=p<.05, \eta^{2}=$ partial eta squared. 
As shown in Table 6, lower secondary school teachers gave the most feedback to their students, whereas upper secondary school teachers gave the least feedback. In the same vein, lower secondary school teachers commented most on their students' progress, and in contrast, upper secondary school teachers commented least. Tukey's posthoc test revealed a statistically significant difference between the lower secondary level and upper secondary school both in the first $(p=.011)$ and in the second $(p=.011)$ claim. The effect sizes were medium for both items (Ellis, 2010).

\section{Consideration of students' course work and competence}

demonstrations in the final assessment

Concerning the fourth research question, the respondents were invited to explain how they took into consideration students' course work and competence demonstrations during the remote teaching period in the final assessment of $9^{\text {th }}$ graders. The respondents $(N=56$, as the question did not pertain to all) commented on whether the student performance during the remote teaching period impacted the final assessment and/or to what extent. Most respondents also mentioned the types of competence demonstration they took into consideration in the final assessment. If a respondent did not specifically mention the impact of the remote teaching period but described assessment methods in numerous ways, it was considered a 'normal impact'. The results are depicted in Figures 1 and 2 below.

\section{Figure 1}

The impact of the remote teaching period on the final assessment

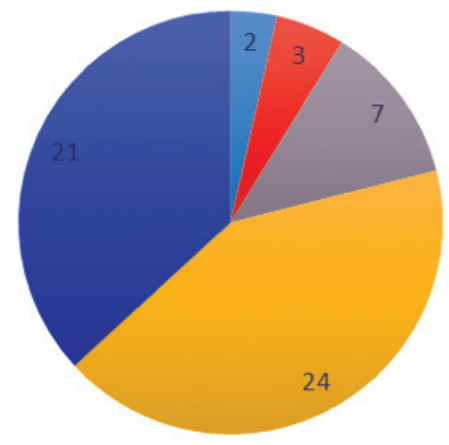
- Not assessed / No grade given
No impact
a Considered if undecided between two grades $\mathbf{n}$ Smaller emphasis
Normal impact 
Most respondents reported that the coursework and competence demonstrations during the remote teaching period had at least some impact on the final assessment of their students. Slightly more than $40 \%$ of the teachers responded that they put less emphasis on the remote teaching period than the rest of the school year. A slightly smaller group of teachers $(37 \%)$ considered student performance during the remote teaching period in the same way as in regular contact teaching. Seven teachers considered student performance during the remote teaching period only if they were undecided between two grades. Three teachers reported that they did not consider the remote teaching period in the final assessment of the language subject. It was also pointed out that student performance during the remote teaching period was not evaluated if the student had a special need for support (one response) and that, according to regular practices and upon a guardian's request, no grades were given for students studying optional language curricula (one response).

The respondents used two points to explain their decision to give no or a lesser emphasis to the remote teaching period. The remote teaching period only covered a small part of the whole syllabus that was evaluated in the final assessment (11 responses, ex. 1; all quotes translated by the authors), and they could not be certain of who had completed the assignments that were turned in (5 responses, ex. 2):

1) The remote teaching period was, after all, a short part of the whole studying time, not decisive. I did not really feel that it would have made giving grades more difficult.

2) A lot of assessment work had already been done for the final assessment, fortunately! During the remote teaching period, it was quite impossible to consider the written work in the final assessment. Because it was possible that anyone had written them. Assessment was focused on oral demonstration.

Example 2 demonstrates that the teachers tried to tackle the questions related to the integrity of student performance by choosing the types of competence demonstration during the remote teaching period that were less likely to be affected, such as oral demonstrations or tasks testing applied skills. 


\section{Figure 2}

Types of competence demonstration taken into consideration in the final assessment

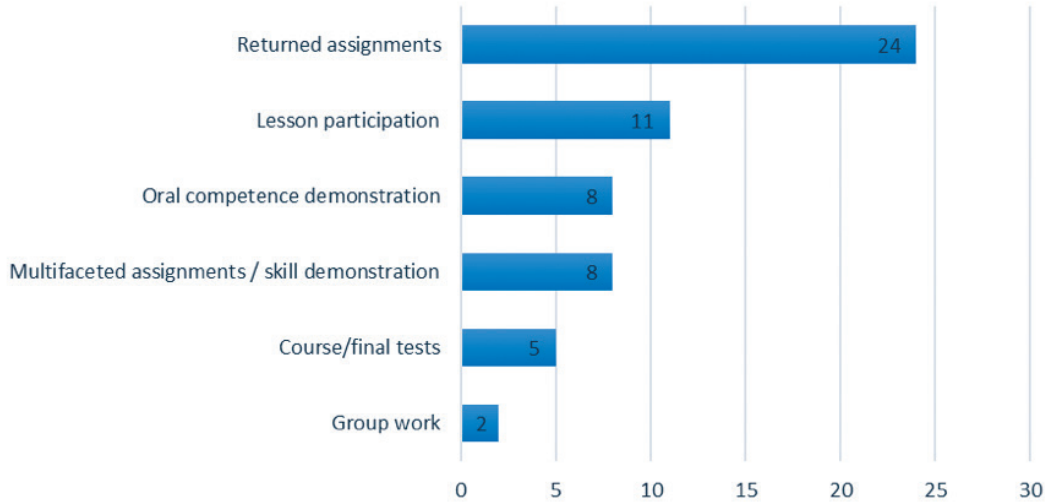

The types of competence demonstration taken into consideration in the final assessment include returned assignments (24 responses), lesson participation in remote classes (11 responses), and oral competence demonstration (8 responses) (see Figure 2). Some respondents did not specify individual task types but wrote that they used multifaceted competence demonstration as the basis for giving assessment (such as written assignments returned on a learning platform, active participation in oral discussion groups, etc.: 8 responses, ex. 3-4). Only five respondents mentioned that they had their students complete either smaller or larger tests that they also considered in the final assessment.

3) I considered each student's work regarding whether s/he completed tasks on time, whether s/he was present and somewhat active in online lessons (I held 'Meet-lessons' in smaller groups so that it was easier to speak the foreign language). During remote teaching, I did not assess all of the students' work. Instead, I informed them beforehand what tasks I would assess.

4) I followed students' written work and its level, actively listened to and guided small group work, and paid attention to progress in tasks on the electronic platforms.

As Examples 3 and 4 demonstrate, the teachers tried to consider multifaceted competence demonstration in the final assessment. 


\section{Discussion}

This study examined how Finnish foreign language teachers perceived their assessment and feedback practices during the remote teaching period in spring 2020. The first two research questions asked about language teachers' perceptions of their assessment practices and feedback practices. Based on the results, most respondents felt that their assessment and feedback practices were implemented successfully. However, the respondents' views varied, and $25 \%$ of the teachers $(N=39)$ considered assessment more challenging than before, while $44 \%(N=69)$ considered it easy. Venäläinen (2020) has found that according to most teachers $(47 \%)$, grading students during remote teaching was not different compared to contact instruction, which agrees with our results. Our results differ somewhat from Niemi and Kousa's (2020) results as they reported that teachers were worried about assessment, especially about the reliability of assessment and the implementation of formative assessment. Nevertheless, Niemi and Kousa (2020) also point out that, in general, teachers exhibited positive perceptions of remote teaching. Many of the respondents in this study ( $37 \%$ of those completing the final assessment of $9^{\text {th }}$ graders) reported that they had completed the assessment the same way as in ordinary classroom teaching.

Regarding feedback, the respondents felt that they had given feedback and commented on their students' progress regularly. The results differ from Tsagari's (2016) results as our study showed that the majority of the teachers were capable of implementing formative assessment (namely feedback) into practice in remote teaching. However, the amount of feedback during the remote teaching period changed from the usual. The results show that teachers gave less oral feedback (either somewhat or considerably for $58 \%$ of respondents) but more written feedback during the remote teaching period than in normal circumstances (either somewhat or considerably, for $78 \%$ of respondents). In the study by Venäläinen (2020), many teachers (48\%) perceived it to be more difficult to give feedback in remote teaching, whereas $28 \%$ of the teachers did not find any difference. In our study, a larger percentage of teachers reported changes in their feedback practices. Teachers have reported in prior studies that their workload increased during the remote teaching period (Ahtiainen et al., 2020; Niemi \& Kousa, 2020; OAJ, 2020); one reason for this could have been the time used to provide increased written feedback. Further, the results show that general upper secondary school teachers gave the least feedback to their students. However, this finding was not surprising because earlier research has established a lack of feedback in general upper secondary courses (e.g., Mäkipää \& Ouakrim-Soivio, 2019). As supportive feedback is focal in online teaching (Simons et al., 2020), we recommend that 
teachers critically examine their feedback practices in online teaching and ponder whether they could be enhanced.

The third research question asked how realistic and reliable language teachers perceived the final assessment of $9^{\text {th }}$ graders. The teachers in our study seemed unanimous that the grades of the $9^{\text {th }}$-grade final assessment were reliable and comparable to the previous years. This finding contradicts those of Ahtiainen and colleagues (2020), who report that teachers were instructed to lower the assessment criteria or not to lower students' grades in some schools. However, it is noteworthy in our study that while teachers unanimously considered the final assessment in the $9^{\text {th }}$ grade to be reliable, their responses considering the reliability of assessment in general during remote teaching were mixed. For example, some teachers commented in the open-response items that assessing student performance was challenging when assignments were turned in remotely and that it was possible to cheat. In the final assessment of the ninth graders, this challenge was easier to deal with since the remote teaching period only covered a small part (the last two months) of the whole syllabus under assessment and, therefore, the teachers had already done a fair amount of assessment by the time remote teaching was launched.

The fourth research question dealt with the issues that the teachers focussed on in the $9^{\text {th }}$ graders' final assessment. Most teachers gave at least some weight to their students' coursework and competence demonstrations in the final assessment during the remote teaching period. Slightly more than one-third of the respondents considered student performance during the remote teaching period in the same way as in regular contact teaching, while about $40 \%$ considered it but with a lesser impact. The types of competence demonstration taken into consideration in the final assessment varied between the respondents. The most common competence demonstration considered for the final assessment was the assignments that students turned in. Furthermore, many teachers paid attention to their students' lesson participation and demonstrations of oral competence. Only a small minority of the respondents had used either smaller or larger tests, which is likely due to the concern that some expressed about not knowing who completes the test or whether other cheating would be involved.

\section{Conclusions}

The results obtained here have implications for developing assessment and feedback practices in online teaching. First, as most respondents in this study were satisfied with their assessment and feedback practices during the remote teaching period, it would be important to share best practices. It also 
became apparent that teachers did not always consider their students' language skills comprehensively for assessment as some felt oral tasks were too difficult or not feasible to carry out in online teaching or were uncertain of who had completed the written tasks. Furthermore, some teachers experienced challenges in providing online feedback. Giving written feedback was also tedious, and it had increased teachers' workload. Therefore, in-service training should emphasise how to provide multifaceted and clear feedback in online teaching.

Second, due to the high amount of online teaching and all the experience gained during the Covid-19 pandemic, it can be speculated that online teaching will be more popular than before, even after the pandemic is over. As assessment is an integral aspect of teaching (Taras, 2005), the art of providing high-quality assessment and feedback, even in online teaching, should be incorporated into the teacher education syllabus and practised alongside in-class assessment and feedback.

Several caveats need to be noted regarding the present study. First, our participants cannot be taken as a representative sample of Finland's whole foreign language teacher population. The participants do not nationally represent Finnish language teachers at all educational levels well, as almost half of them live in the metropolitan area of Helsinki, and nearly all the participants were female. Concerning types of school, the number of participants from vocational schools or adult education and training was relatively low. Furthermore, teachers who are active on social media might have been inclined to answer the questionnaire more easily as they could have come across the invitation more effortlessly than those who received only an e-mail. In general, in the type of questionnaire that respondents can self-select whether to respond, it is expected that those who feel strongly about it, either positively or negatively, will participate (Dewaele, 2018).

Despite the caveats mentioned above, this study has successfully demonstrated how language teachers perceived their assessment and feedback practices during the remote teaching period in Finland in spring 2020. Nevertheless, further investigations are needed to examine how students have perceived teachers' assessment and feedback practices during the remote teaching period. Specifically, more research is needed to assess whether students felt that they received sufficient, appropriate, and supportive feedback for suitable tasks, how reliable assessment was from their perspective, and whether they could demonstrate their language competence in multifaceted ways. 


\section{References}

Ahtiainen, R., Asikainen, M., Heikonen, L., Hienonen, N., Hotulainen, R., Lindfors, P., Lindgren, E., Lintuvuori, M., Oinas, S., Rimpelä, A., \& Vainikainen, M-P. (2020). Koulunkäynti, opetus ja hyvinvointi kouluyhteisössä koronaepidemian aikana: Ensitulokset [Schoolgoing, teaching and wellbeing in school community during the corona pandemic: Initial results]. HEA, NEDIS, REAL. Anderson, L. W. (2003). Classroom assessment: Enhancing the quality of teacher decision making. Lawrence Erlbaum Associates.

Braun, V., \& Clarke, V. (2006). Using thematic analysis in psychology. Qualitative Research in Psychology, 3(2), 77-101.

Butler, S. M., \& McMunn, N. D. (2014). A teacher's guide to classroom assessment: Understanding and using assessment to improve student learning. John Wiley \& Sons.

Dewaele, J.-M. (2018). Online questionnaires. In A. Phakiti, P. DeCosta, L. Plonsky, \& S. Starfield (Eds.), The Palgrave handbook of applied linguistics research methodology (pp. 269-286). Palgrave Macmillan.

Dörnyei, Z. (2020). Innovations and challenges in language learning motivation. Routledge. Ellis, P. D. (2010). The essential guide to effect sizes: Statistical power, meta-analysis, and the interpretation of research results. Cambridge University Press.

Finnish National Agency for Education. (2020). Education services and the coronavirus. https://www. oph.fi/en/news/2020/education-services-and-coronavirus

FNBE [National core curriculum for basic education 2014]. (2016a). Finnish National Board of Education, Publications.

FNBE [National core curriculum for general upper secondary schools 2015]. (2016b). Finnish National Board of Education, Publications.

Hattie, J., \& Timperley, J. (2007). The power of feedback. Review of Educational Research, 77(1), $81-112$.

Hattie, J., \& Zierer, K. (2019). Visible learning insights. Routledge.

Hilli, C. (2020). Distance teaching in small rural primary schools: A participatory action research project. Educational Action Research, 28(1), 38-52.

Leibold, N., \& Schwarz, L. M. (2015). The art of giving online feedback. The Journal of Effective Teaching, 15(1), 34-46.

Linnakylä, P., \& Välijärvi, J. (2005). Arvon mekin ansaitsemme. Kansainvälinen arviointi suomalaisen koulun kehittämiseksi [Worthy of recognition? International assessment and the development of the Finnish School]. Ps-Kustannus.

Mackey, A., Park, H. I., \& Tagarelli, K. M. (2016). Errors, corrective feedback and repair: variations and learning outcomes. In G. Hall (Ed.), The Routledge handbook of English language teaching (pp. 499-512). Routledge.

Mäkipää, T., \& Ouakrim-Soivio, N. (2019). Perceptions of Finnish upper secondary school students of the assessment practices of their teachers. Journal of Teaching and Learning, 13(2), 23-42. 
Niemi, H. M., \& Kousa, P. (2020). A case study of students' and teachers' perceptions in a Finnish high school during the COVID pandemic. International Journal of Technology in Education and Science, 4(4), 352-369.

Niemi, H., Toom, A., \& Kallioniemi, A. (Eds.) (2016). Miracle of education: The principles and practices of teaching and learning in Finnish schools (2nd Rev. Ed.). Sense Publishers.

OAJ [Trade Union of Teachers in Finland]. (2020). OAJ:n kysely koskien opetuksen poikkeusjärjestelyjä keväällä 2020. Tiivistelmä [Survey regarding the exceptional teaching arrangements in spring 2020. Summary] https://www.oaj.fi/ajankohtaista/uutiset-ja-tiedotteet/2020/koronavirus-kysely/ Pollari, P. (2020). “Mitä pitäisi kehittää ja miten?” Lukiolaisten kokemuksia arvioinnista ja sen menetelmistä englannin opinnoissa ["What should be improved and how?" Students' experiences of assessment and its methodology in their upper secondary English studies"]. In R. Hildén \& K. Hahl (Eds.), Kielididaktiikan katse tulevaisuuteen: haasteita, mahdollisuuksia ja uusia avauksia kielten opetukseen (pp. 153-171). Suomen ainedidaktisen tutkimusseuran julkaisuja, Ainedidaktisia tutkimuksia 17.

Purpura, J. E. (2016). Second and foreign language assessment. The Modern Language Journal, 10o, $190-208$.

Ruiz-Primo, M. A., \& Brookhart, S. M. (2018). Using feedback to improve learning. Routledge. Simons, J., Leverett, S., \& Beaumont, K. (2020). Success of distance learning graduates and the role of intrinsic motivation. Open Learning: The Journal of Open, Distance and e-Learning, 35(3), 277-293. Simonson, M., \& Seepersaud, D. J. (2019). Distance education: Definition and glossary of terms (4th Ed.). Information Age Publishing.

Statistics Finland. (2021). Education. https://www.stat.fi/til/kou_en.html Stenman, S., \& Pettersson, F. (2020). Remote teaching for equal and inclusive education in rural areas? An analysis of teachers' perspectives on remote teaching. The International Journal of Information and Learning Technology, 37(3), 87-98.

SUKOL (The Federation of Foreign Language Teachers in Finland). (2020). https://www.sukol.fi/ liitto/mika_sukol_on/other_languages

Tanhua-Piiroinen, E., Kaarakainen, S-S., Kaarakainen, M-T., \& Viteli, J. (2020). Digiajan peruskoulu II [Comprehensive schools in the digital age II]. Publications of the Ministry of Education and Culture, Finland 2020.

Taras, M. (2005). Assessment - summative and formative - some theoretical reflections. British Journal of Educational Studies, 53(4), 466-478.

Toppin, I. N., \& Toppin, S. M. (2016). Virtual schools: The changing landscape of K-12 education in the U.S. Education and Information Technologies, 21, 1571-1581.

Tsagari, D. (2016). Assessment orientations of state primary EFL teachers in two Mediterranean countries. CEPS Journal, 6(1), 9-30.

Vanhatalo, U., \& Vehkalahti, K. (2020). Kysely [Questionnaire]. In M. Luodonpää-Manni, M. Hamunen, R. Konstenius, M. Miestamo, U. Nikanne, \& K. Sinnemäki (Eds.), Kielentutkimuksen menetelmiä (pp. 240-273). SKS. 
Venäläinen, S. (2020). Etäopetus ja tasa-arvo [Remote teaching and equality]. Tempus 5/2020, 12-13. Vocational Education and Training Act. (531/2017). https://www.finlex.fi/fi/laki/alkup/2017/20170531 Wisniewski, B., Zierer, K., \& Hattie, J. (2020). The power of feedback revisited: A meta-analysis of educational feedback research. Frontiers in Psychology, 10, 1-14.

\section{Biographical note}

ToNı MäKIP̈̈̈̈, MA, is a doctoral student at the Faculty of Educational Sciences, University of Helsinki, Finland. He has extensive teaching experience from comprehensive school and the university level. Mäkipääs research interests include assessment, assessment literacy, foreign language learning, self-regulation, and remote teaching.

KaISA Hahl, PhD, Adjunct Professor, is a University Lecturer in Foreign Language Education and a teacher educator at the Faculty of Educational Sciences, University of Helsinki in Finland. She is the responsible person for subject teacher education at the faculty. Hahl's research interests focus on foreign language teaching, intercultural education, and teacher development. Hahl has also several years' experience in international teacher education development projects.

Milla Luodonpä̈̈-MannI, PhD, is a University Lecturer in Foreign Language Education and a teacher educator at the Faculty of Educational Sciences, University of Helsinki, Finland. Her research interests include language education, the interconnection between language and wellbeing, and the study and teaching of scientific writing. 